\title{
Greatlakean Substage: A Replacement for Valderan Substage in the Lake Michigan Basin
}

\author{
EDWARD B. EVENSON \\ Department of Geological Sciences, Lehigh University, Bethlehem, \\ Pennsyluania 18015 \\ WILLIAM R. FARRAND AND DONALD F. ESCHMAN \\ Department of Geology and Mineralogy, University of Michigan, \\ Ann Arbor, Michigan 48104 \\ AND

\begin{abstract}
DAVID M. MICKELSON AND LOUIS J. MAHER Madison, Wisconsin 53706
\end{abstract} \\ Department of Geology and Geophysics, University of Wisconsin,
}

Received July 30, 1975

\begin{abstract}
New evidence from recent field and seismic investigations in the Lake Michigan basin and in the type areas of the Valders, Two Creeks and Two Rivers deposits necessitates revision of late-glacial ice-front positions, rock- and time-stratigraphic nomenclature and climatic interpretations and deglaciation patterns for the period ca. 14,000-7,000 radiocarbon years B.P. The previously reported and long accepted pattern of deglaciation for the Lake Michigan basin started with a regular retreat from the Lake Border Morainic System, with a minor oscillation marked by the Port Huron moraine(s) and then an extensive Twocreekan deglaciation followed by a major $(320 \mathrm{~km})$ postTwocreekan advance (Valders). However, we now record a major retreat between the times of the Lake Border and Port Huron moraines, followed by a gradual retreat from the Port Huron limit and interrupted by a minor standstill (deposition of Manitowoc Till), a retreat (Twocreekan) and a readvance (Two Rivers Till). No Woodfordian or younger readvance was as extensive as had been the preceding one. This sequence argues for a normal, climatically controlled, progressive deglaciation rather than one interrupted by a major post-Twocreekan (formerly Valderan) surge. This revision appears finally to harmonize the geologic evidence and the palynological record for the Great Lakes region. Our investigations show that Valders Till from which the Valderan Substage was named is late-Woodfordian in age. We propose the term "Greatlakean" as a replacement for the now misleading time-stratigraphic term "Valderan." The type section and the definition of the upper and lower boundaries of the Greatlakean Substage remain the same as those originally proposed for the Valderan Substage but the name is changed.
\end{abstract}

\section{INTRODUCTION}

Since the classic investigations of Chamberlin (1878), Leverett (1899; Leverett and Taylor, 1915), Alden (1918), and Leighton $(1957,1933)$, the Great Lakes region has been the "type area" for the stratigraphic subdivisions of the late-glacial period of North
America. Repeated attempts at regional (e.g., Dreimanis and Goldthwait, 1973; Zumberge, 1960; Wright, 1971b; Richmond, 1965; Lemke et al., 1965; Frye and Leonard, 1965) and intercontinental (e.g., Dreimanis and Karrow, 1972; Broecker and Farrand, 1963; Mörner, 1970; Dansgaard et al., 1971; Richmond, 
1965) correlation have been presented and will continue to appear; therefore, stratigraphic and nomenclatural revisions in this key area have widespread impact. Recent investigations in the Lake Michigan basin and adjacent areas provide new data which necessitate revision of late-glacial ice-front positions, rock- and time-stratigraphic nomenclature, and climatic interpretations for the period ca. 14,000-7,000 B.P. In addition, we question the need for the concept of glacial surging in the Lake Michigan basin and perhaps resolve some problems long associated with interpretation of the palynological record for this period of time (Wright, 1971a; Cushing, 1967; Wright et al., 1963; Saarnisto, 1974).

Recent geomorphic and stratigraphic studies by the authors (Evenson, 1973a, 1973b, Evenson and Mickelson, 1974; Mickelson and Evenson 1975; Farrand 1970) and seismic investigations by the Illinois State. Geological Survey (Lineback et al., 1974) have demonstrated that the age and stratigraphic relations of the red tills and lacustrine deposits in the Lake Michigan basin are considerably more complex than previously assumed (Bretz, 1951; Thwaites and Bertrand, 1957). Until the present series of studies by the authors and Lineback et al. (1974) all red tills in the area were considered, by most authors, to be age equivalent ("Valderan"), that is, younger than the Two Creeks forest bed, although certain early workers (e.g., Alden, 1918) had recognized some pre-Twocreekan red tills.

Evenson (1973a,b) and others (Lineback et al., 1974; Farrand, 1970; Farrand et al., 1969) have demonstrated the presence of pre- and postTwocreekan red tills in the Lake Michigan basin, and Evenson (1973) suggested that the type Valders Till was preTwocreekan (Woodfordian) in age. Subsequent work, supported by mapping and drilling (Evenson and Mickelson, 1974), confirms this correlation. Evenson (1973a) proposed the name "Two Rivers Till" for the till overlying the Two Creeks forest bed and retained the name "Valders Till" for the stratotype till at Valders, Wisconsin as originally formally defined by Thwaites $(1943$, p. 121) long before the present Code of Stratigraphic Nomenclature (1961) was written. The history and evolution of this terminology is reviewed in detail by Evenson (1973a,b) and Farrand (1976).

Seismic and lithologic studies by the Illinois State Geological Survey (Lineback et al., 1974) confirm our observations of pre- and post-Twocreekan red tills and provide a further subdivision of the late-Woodfordian (pre-Twocreekan) deposits south of the Two Rivers limit (Fig. 1). The Illinois Survey names and describes two late-Woodfordian red tills on the floor of the Lake Michigan basin and suggests correlations with units above lake level. The Shorewood Till is correlated with the red till "found along the lake shore at Milwaukee and Muskegon." The Manitowoc Till is correlated with "the till that underlies the Two Creeks forest bed." We have not yet attempted to separate the equivalents of the Manitowoc and Shorewood Tills on land, although we suspect it may be possible. In Wisconsin, we currently use the term "Valders Till" for the red till at the Valders type locality and informally apply the terms "Manitowoc till" and "Shorewood till" as discussed in the section on late-Woodfordian deposits. In Michigan no formal rock-stratigraphic terms are applied, the red tills south of the Two Rivers limit being informally called "Port Huron till." Possibly the Manitowoc and Shorewood Tills of the Lake Michigan basin are equivalent to the tills of the inner and outer Port Huron moraines of Michigan as defined by Leverett and Taylor (1915); see also Farrand and Eschman (1974).

In this paper we will examine what is now known about the extent and timing of late-glacial advances and retreats in 


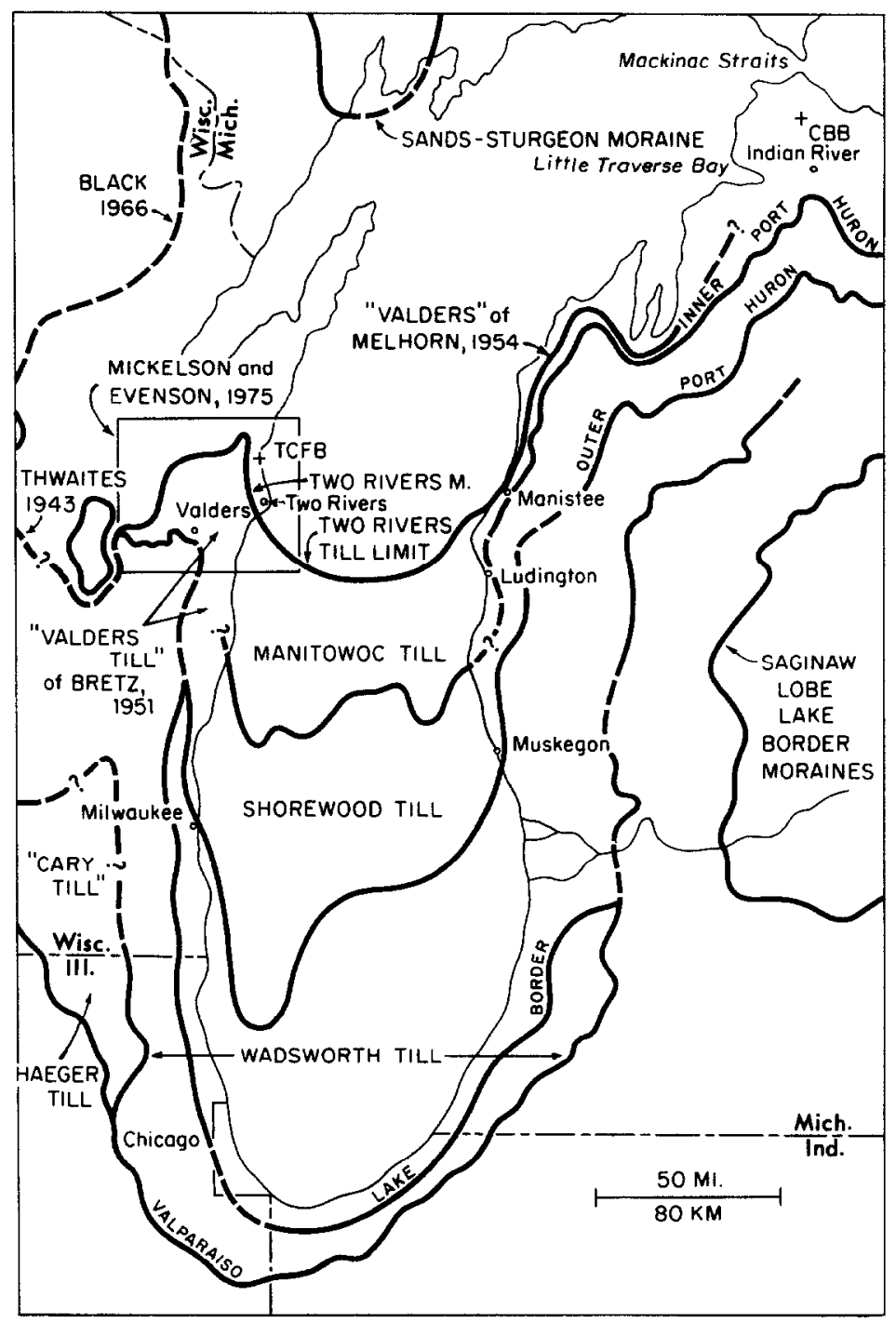

FIG. 1. Ice-front positions, rock-stratigraphic units, and major moraines in and adjacent to the Lake Michigan basin. Positions in Southern Peninsula of Michigan after Farrand and Eschman, 1974, and Melhorn, 1954; Indiana after Schneider and Keller, 1970; and Bretz, 1951; Illinois after Willman and Frye, 1970; Southeastern Wisconsin after Bretz, 1951. Valders-Two Rivers area after Evenson and Mickelson, 1974; Northwestern Michigan after Martin, 1955; Lake Michigan after Martin, 1955; Lake Michigan basin modified (according to Evenson, 1973a) from Lineback, Gross and Meyer, 1974.

the Lake Michigan basin and, based on this information, we will propose changes in the time-stratigraphic nomenclature of the late Wisconsinan Lake Michigan lobe.

\section{TIME-SPACE RELATIONS AND NOMENCLATURE}

Figure 2 is a time-space diagram for the Lake Michigan area from approxi- mately $14,000-10,000$ radiocarbon years B.P. This diagram is constructed by plotting, to scale, logical ice margin reconstructions along a north-south line parallel to the axis of deglaciation of the Lake Michigan glacial lobe. All of our suggested revisions of ice-front positions and nomenclature are included on this diagram. Correlations of various till units are also shown. Informal units are in. 


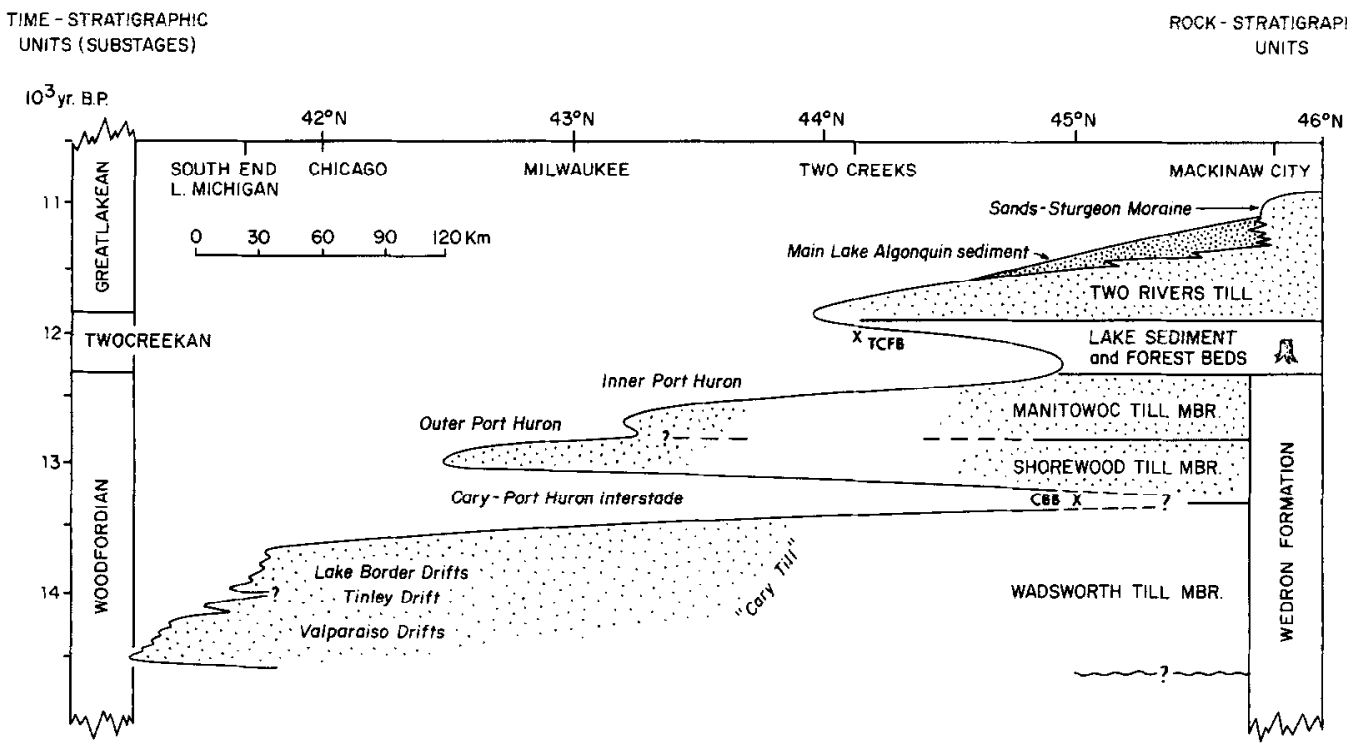

FIG. 2. Time-distance diagram for the Lake Michigan basin. Vertical scale represents time in thousands of radiocarbon years B.P.; the horizontal scale is the approximate distance along the glacial path of the Lake Michigan Lobe. Formal rock-stratigraphic and time-stratigraphic terms shown in bold type. Informal units, drifts and moraines shown in italics; T.C.F.B. = Two Creeks Forest Bed; C.B.B. = Cheboygan Bryophyte Bed, these localities are projected into the lake basin along logical ice margins to maintain their proper stratigraphic position.

cluded to make the diagram more useful on a regional basis.

Numerous changes in ice-front positions and nomenclature are presented in this diagram which differs significantly from previous diagrams for this area and period of time (Frye et al., 1960, 1965, 1973). Among the most important changes shown are: (1) a significant glacial retreat $(400 \mathrm{~km}$ ) during the CaryPort Huron interstade, (2) a threefold subdivision of the red drift in the Lake Michigan basin showing two Woodfordian drifts and one post-Twocreekan (Greatlakean) drift, (3) a much smaller deglaciation during the Twocreekan than previously assumed, (4) a reduction by nearly $175 \mathrm{~km}$ of the post-Twocreekan advance, the advance which covered the forest bed, and (5) a substitution of the term "Greatlakean" for the timestratigraphic term "Valderan."

\section{CARY-PORT HURON INTERSTADE}

The most significant glacial retreat recorded occurred between the time of the Lake Border moraines (Wadsworth Till Member) of Illinois, Indiana, and S.W. Michigan and the time of the early Port Huron moraine (Shorewood Till Member) of Michigan and.Wisconsin (Fig. 1). Both till sheets are considered Woodfordian in age by us and by the Illinois Geological Survey, making the interstade an intra-Woodfordian event (CaryPort Huron). Evidence for the position of the ice-front during this interstade is provided by the Cheboygan . County Bryophyte Bed reported by Farrand et al. (1969). The bryophyte bed consists of a 1-cm-thick mat of mosses and leaves of Dryas integrifolia between two red clay tills. The bryophyte bed is about 13,000 years old (Farrand et al., 1969) and indicates ice retreat at least this far north on land during the CaryPort Huron interstade. No evidence can be presented to demonstrate the maximum extent of this retreat, but it was probably farther north than the bryophyte locality, as suggested on the diagram. The Cary-Port Huron interstade 
is, properly speaking, a geologic-climate unit (American Commission on Stratigraphic Nomenclature, 1961); sediments representing this time interval have not been formally defined as a timestratigraphic unit in the Lake Michigan lobe area, although Dreimanis and Karrow (1972) have proposed the timestratigraphic term "Mackinaw Interstadial" for the time represented by the bryophyte bed.

\section{LATE-WOODFORDIAN DEPOSITS}

Following the Cary-Port Huron retreat, the ice readvanced to Shorewood-outer Port Huron-Valders limit shown on Figs. 1 and 2. The ice advanced into waters of Glacial Lake Chicago which stood at the Glenwood level (640 $\mathrm{ft}$ above sea level) and drained south via the Chicago outlet. The drift deposited during this advance is mapped in the Lake Michigan basin as the "Shorewood Till Member of the Wedron Formation" by Lineback et al. (1974) and is assigned a late-Woodfordian age. The Shorewood Till Member is a pink to red clayey till that forms a prominent terminal moraine on the lake floor. This subaqueous moraine appears to correlate with the outer Port Huron (or Whitehall) moraine along the lake shore at Muskegon (Farrand and Eschman, 1974) and with the red till limit (Valders till of Bretz, 1951) occurring as far south as Milwaukee, Wisconsin (Fig. 1). This latter red till is equivalent to the Shorewood Till Member near Milwaukee, but its correlation with Shorewood, Manitowoc, or Valders tills is problematical north of the point where the Manitowoc Till Member passes on land from the lake bottom (Fig. 1). The term "Valders Till" is omitted from Fig. 1 because of this uncertainty in its correlation. The authors currently reserve the name "Valders Till" for the red till at the Valders type locality in Wisconsin and consider the deposit to be pre-Twocreekan (Mickelson and Evenson, 1975).
The next recorded event in the Lake Michigan basin is the deposition of the Manitowoc Till Member of the Wedron Formation (Figs. 1 and 2). Whether deposition of this unit was preceded by a significant deglaciation is not known. Compositional and slight color differences between the Shorewood and Manitowoc Till Members are reported by Lineback et al. (1974), but may be artifacts of small sample size or may reflect upglacier shifts in the source area rather than retreat and readvance. The southern limit of the Manitowoc Till Member is not marked by an end moraine; this may argue for simple retreat and a relatively short occupation of this ice border.

Retreat from the Manitowoc limit occurred prior to the drop from the Glenwood stage of Glacial Lake Chicago, as Glenwood shoreline features are developed on red tills north of its logical landward extension (Evenson, 1973).

Division of the onshore red Woodfordian till into formal rock-stratigraphic units equivalent to the Shorewood and Manitowoc Tills of the lake basin has not yet been attempted, but we suspect that careful lithologic and geomorphic work will provide the criteria necessary for this subdivision. Evenson (1973) recognized a hummocky complex immediately south of Manitowoc, Wisconsin, which would provide a logical landward extension of the Manitowoc Till (Fig. 2), and Lineback et al., (1974) suggested that the Manitowoc Till Member is equivalent to the till that underlies the Two Creeks forest bed, which is reasonable. Prior to the discovery of two red Woodfordian tills in the lake basin, Evenson (1973) suggested that the red till below the forest bed was equivalent to the typeValders Till at Valders, Wisconsin. However, we must now ask: "Which of the red tills in the lake basin is correlative with the type-Valders Till?" Further investigation will be required to answer this question. In the type-Valders-Two Rivers-Two Creeks area (Fig. 1) Evenson 
and Mickelson (1974; Mickelson and Evenson, 1975) have separated pre- and post-Twocreekan tills on the basis of directional indicators, forest bed distribution and depth of carbonate leaching.

In Michigan, a division of the Port Huron moraine system into "inner Port Huron" and "outer Port Huron" has long been established (Leverett and Taylor, 1915, p. 303) and accepted. On the basis of the demonstration by Lineback et al. (1974) of a similar twofold division of the late-Woodfordian drift in the Lake Michigan basin, we tentatively correlate the advance that formed the outer Port Huron moraine of Michigan with the advance which deposited the Shorewood Till Member in the Lake Michigan basin. Likewise, the inner Port Huron advance is correlated with the advance which deposited the Manitowoc Till Member (Fig. 2). However, along the west coast of southern Michigan we have not yet been able to identify a specific outer-inner Port Huron limit among the highly segmented morainic hills of that area.

As the ice retreated from the Manitowoc Till limit, Glacial Lake Chicago (Glenwood stage) expanded northward and lacustrine features developed on red till along the lake margin. Evenson (1973) traced these features continuously to a point immediately north of Manistee, Michigan, and immediately south of Two Rivers, Wisconsin. In the Twin Rivers lowland of Wisconsin, a large lacustrine-deltaic complex, identified as "Lake Shoto" by Thwaites and Bertrand (1957), has now been recognized by Evenson (1973) and Mickelson and Evenson (1975) to be graded to the Glenwood Lake Chicago. Its presence restricts the later Two Rivers advance to a point north or east of this locality and precludes the possibility of post-Twocreekan glaciation by the Lake Michigan lobe at the Valders type-locality. At Manistee, Michigan, a pitted outwash plain graded to the Glenwood level documents a high lake stand until the ice had retreated at least this far north. As all of the Glenwood stage is preTwocreekan (Eschman and Farrand, 1970), the red tills beneath and south of this limit must also be pre-Twocreekan.

\section{TWOCREEKAN DEGLACIATION}

Continued retreat of the Woodfordian ice eventually uncovered a low eastwarddraining outlet for Glacial Lake Chicago, and the water level in the Lake Michigan basin fell to the Two Creeks low-water stage. At this time the Two Creeks forest bed developed a few miles north of the city of Two Rivers, Wisconsin. The age (11,850 \pm 100 B.P.) and stratigraphy of the forest bed are described elsewhere by Broecker and Farrand (1963), Black (1970), and Evenson (1973) and will not be discussed in detail here; we wish only to comment on evidence bearing on the extent of deglaciation during Twocreekan time.

Farrand et al. $(1974 ; 1969)$ present evidence which argues for less retreat during Twocreekan time than previously assumed. Some earlier interpretations have suggested a considerable retreat of the ice-front well into the Lake Superior basin (Hough, 1963), whereas others indicated a minimal retreat, just sufficient to open the Straits of Mackinac (Prest, 1970). The lack of any break, either stratigraphic or lithologic, in the red till section overlying the Cheboygan bryophyte bed argues that not even the Straits of Mackinac were deglaciated during Twocreekan time. The eastward drainage required by the Two Creeks lowwater stage and development of the forest bed could have been accommodated by the Indian River lowland (east of Little Traverse Bay, Michigan) instead of by the Straits of Mackinac. These facts place maximum and minimum limits on the extent of the deglaciation, during Twocreekan time, in the Cheboygan County area of Michigan and allow 
us to project a logical deglaciation limit into the Lake Michigan basin as shown in Fig. 2. This interpretation reduces the previous estimates of the amount of deglaciation by at least $30 \mathrm{~km}$.

\section{THE POST-TWOCREEKAN ADVANCE}

Our interpretation of the post-Twocreekan (Two Rivers) limit in and adjacent to the Lake Michigan basin is shown in Figs. 1 and 2. The ice position within the lake basin is modified slightly from Lineback et al. (1974) on the basis of the work of Evenson (1973a). The onshore distribution is from Melhorn (1954) and from recent work by the authors (Evenson, 1973a, 1973b; Evenson and Mickelson, 1974; Mickelson and Evenson, 1975; Farrand, 1970), as reviewed in this paper. The delineation of the Two Rivers Till (and its equivalents) shown here reduces the extent of the post-Twocreekan readvance by nearly $175 \mathrm{~km}$ along the axis of the Lake Michigan basin and precludes its correlation with either the type-Valders Till or the red tills occurring south of Two Rivers, Wisconsin and Manistee, Michigan. Our reduction of both the postTwocreekan advance and the Twocreekan retreat (Fig. 2) defines a post-Twocreekan advance of approximately 125 $\mathrm{km}$. The climatic and glaciologic implications of this revision are discussed below.

As the ice retreated from the Two Rivers Till limit, the local center of glacier outflow apparently shifted from the Lake Michigan trough to the eastcentral Lake Superior basin as shown by Wright (1971b) and Saarnisto (1974). According to Saarnisto (1974), ice from this source occupied the northwesternmost portion (Figs. 1 and 2) of the Lake Michigan basin approximately 11,000 B.P. Specifically, the ice-front was standing at the Sands-Sturgeon moraine (Martin, 1955) at the north end of
Green Bay at that time. With retreat from this ice position, the Lake Michigan basin became ice-free and its history from this point is recorded by a series of glacial lakes which are not the subject of this report.

\section{INTERPRETATION AND REVISION OF NOMENCLATURE}

Our revision of the deglaciation history of the Lake Michigan basin necessitates a reappraisal of the relative importance of some well-known late-glacial events. As shown in Fig. 2, the amount of retreat during the Cary-Port Huron interstade (ca. $400 \mathrm{~km}$ ) far exceeds that during the Twocreekan time (ca. $120 \mathrm{~km}$ ), and the post-Twocreekan (Two Rivers) advance has been reduced by over $17.5 \mathrm{~km}$. Therefore, in place of the previously assumed major deglaciation (Twocreekan time) followed by a major readvance (Valderan time), we have evidence of a gradual retreat from the Port HuronShorewood limit with only a minor readvance in post-Twocreekan time. No subsequent readvance in this series was as extensive as the preceding ones. This change in the interpretation of the mode of deglaciation may obviate the necessity for the surge hypothesis in the Lake Michigan basin (see Wright, 1971b, 1973; Prest, 1970).

Moreover, in light of this revision, the Two Creeks and Valders episodes no longer can be viewed as outstanding events of Lake Michigan lobe history. Since these terms and concepts are in widespread use, it is appropriate for us to consider possible modifications or redefinitions of these terms. In doing this, we are trying to keep in mind that nomenclature, stratigraphic or otherwise, should serve a pragmatic end, namely that of easy and clear mutual understanding.

The Twocreekan Substage as proposed by Frye et al. (1960) is a valid subdivi- 
sion as defined and requires little modification. Willman and Frye's (1970) definition of the Twocreekan Substage is explicitly based on Thwaites and Bertrand's (1957) description of the Two Creeks forest bed locality. It includes all lacustrine, fluvial and organic sediments above Woodfordian till and below the overlying red till in the classic deposits near Two Creeks, Wisconsin. However, we place the upper limit of the Twocreekan Substage at $11,850 \pm 150$, the time of destruction of the forest at its type locality, and we reject Willman and Frye's (1970) extrapolation of this substage to 11,000 B.P. If Saarnisto's (1974) interpretations are correct, 11,000 B.P. would be considerably too young for the end of the Twocreekan.

The name "Valderan" was taken for the post-Twocreekan Substage from the Valders Till of Wisconsin by Frye- and Willman (1960) under the then accepted assumptions that all young red tills in the area were the same age; therefore, it was logical to assume that the red till over the Two Creeks forest bed was Valders till. However, we have shown that there are pre- and post-Twocreekan red tills over the Two Creeks forest bed. The name "Valders Till", is now restricted to. the pre-Twocreekan substage (Woodfordian) (Evenson, 1973a, Evenson and Mickelson, 1974; Mickelson and Evenson, 1975; Evenson et al., this report). Therefore, the use of Valderan for the post-Twocreekan substage is invalid and misleading. For this reason we here propose the new term "Greatlakean Substage" as a replacement for the Valderan Substage.

Our justification for this revision is as follows. First, the definition of the Valderan Substage is technically invalid. Willman and Frye (1970, p. 126) and Willman et al. (1975) define the base of the substage as "the contact of the Valders till on the Two Creeks forest bed." However, our studies (Evenson,
1973; Evenson and Mickelson, 1974; Mickelson and Evenson, 1975) demonstrate that the type-Valders Till at Valders, Wisconsin, is pre-Twocreekan in age. Therefore, the till (Two Rivers Till) over the forest bed is neither Valders Till, nor does it correlate with the Valders Till. This discovery alone invalidates the definition of the Valderan Substage. Secondly, continued usage of "Valderan". as a term for a substage which does not include the type-Valders Till is awkward, if not inappropriate. Although Willman et al. (1975) argue for retention of the terms "Valderan" and "Valders Till" we feel that until either the Valders Till or the Valderan Substage are renamed, confusion will reign. As the Valders Till was formally named by Thwaites in 1943, it clearly has priority. Finally, from past usage the terms "Valders" and "Valderan" have come to be associated with the readvance (or surge) to the red till limit near Milwaukee, Wisconsin, and Muskegon, Michigan; this would be misleading if the term "Valderan" were retained to include only the Two Rivers Till and its equivalents which occur nearly $125 \mathrm{~km}$ north of Milwaukee and Muskegon.

The term "Greatlakean" is selected because of its regional connotation, which appears appropriate for a timestratigraphic unit. It was during the Greatlakean Substage that the modern Great Lakes evolved to approximately their present configuration. In keeping with our intent to rename rather than redefine the "Valderan" Substage, we retain with substitutions Willman and Frye's (1970) basic definition of the rock-stratigraphic basis for the substage. In the definition of the base of the substage, the term "Two Rivers Till" is substituted for "Valders Till"' (see above). Frye and others (1968; and Willman and Frye, 1970) define the top of the Valderan as "the top of the Cochrane till and its contact with overlying thin 
discontinuous post-Cochrane deposits in the James Bay Lowland of Ontario, Canada (Hughes, 1956, p. 5; 1965)." In 1956, Hughes considered the glaciolacustrine sediments on top of the Cochrane till as post-Cochrane (postWisconsin; see Hughes, 1956 , p. 5; map 5541 ) but in 1965 , he included the glaciolacustrine sediments in the Cochrane Formation of Pleistocene (Late Wisconsin) age. However, from their description it is evident that Frye and his co-workers intended the top of the Cochrane till below glaciolacustrine deposits as the rock-stratigraphic basis for the end of their Valderan Substage. This boundary is recognizable and has been described in a suitable type section (Hughes, 1965, p. 545) whereas the upper boundary of the glaciolacustrine sediments has not been described. Thus, the rock-stratigraphic basis for the top of the Greatlakean is the top of Cochrane till and its contact with overlying thin discontinuous glaciolacustrine deposits in the James Bay Lowland of Ontario, Canada. We have substituted the term "glaciolacustrine" for "post-Cochrane" but otherwise retain the definition of Frye and others (1968). The type locality for the top of the Greatlakean is at the type locality for the Cochrane Formation as described by Hughes (1965, p. 544-546). This places the end of the Greatlakean Substage at approximately 7000 radiocarbon years B.P. according to Willman and Frye (1970) and at greater than 8275 radiocarbon years B.P. according to Hughes (1965). Thus, the absolute age of the end of the Greatlakean at its.type locality is approximate at best. The Greatlakean is the last substage of the Wisconsinan Stage and is, according to Willman and Frye (1970, p. 126), followed by the Holocene Stage, a concept with which we agree. A review of the recent literature demonstrates that there is no clear consensus as to the age and definition of the beginning of the Holocene Stage. Various authors have placed the boundary "within nearly every millenium from 18,000 to 4000 years ago" (Hopkins, 1975). However, the Holocene Commission of the International Quaternary Association now favors placing the global PleistoceneHolocene boundary at 10,000 radiocarbon years B.P. and although no stratotype currently exists where this boundary is geochronometrically dated one is actively being sought (see Hopkins, 1975; Fairbridge, 1974; Mörner, 1973). Thus, the Greatlakean-Holocene boundary (Pleistocene-Holocene) as defined in the Great Lakes area is, apparently, somewhat younger than that favored for the worldwide reference boundary. We consider the Greatlakean Substage and all other units of this rank or lower (i.e., Woodfordian, Twocreekan) in the Great Lakes region as a Local Chronostratigraphic Unit, as defined by the International Subcommission on Stratigraphic Classification (1970; Article VII-H) and apply the term as discussed in Article VII-I. The GreatlakeanHolocene boundary is a regional boundary (see Terasmae, 1972) and is proposed for the Great Lakes region of the United States and Canada. No attempt is made by us to define "a reference boundary in terms of an international stratotype with a worldwide validity as the chronostratigraphic boundary between the chronostratigraphic units "Pleistocene" and "Holocene" as described by Terasmae (1972). When defined formally, and if the age of 10,000 radiocarbon years is accepted, the worldwide Pleistocene-Holocene time-stratigraphic boundary will likely occur within the local time-stratigraphic Greatlakean Substage (Fig. 2). This is acceptable (Article VII-I, International Subcommission on Stratigraphic Classification Report No. 4, 1970) as local time-stratigraphic units based on rock-stratigraphic units representing for the most part glacial- 
climatic events can hardly be expected to be synchronous on a worldwide basis.

\section{PALYNOLOGY}

Our interpretation of the pattern of deglaciation in the Lake Michigan basin may allow us to resolve some of the problems associated with the interpretation of the late-glacial palynological record. Pollen analysts have long been tantalized, as well as frustrated, by the presence of the well-dated Two Creeks forest horizon. At first, this stratigraphic sequence was regarded as the New World equivalent of the European Aller $\phi d$ (Andersen, 1954). Wiggles in the pollen curves in the lower part of late-glacial pollen diagrams were related to vegetation response to the hypothetical climate deterioration that caused the ice advance to the then assumed post-Twocreekan limit at the latitude of Milwaukee and Muskegon (Fig. 1). Then Broecker and Farrand (1963) demonstrated that the Two Creeks interval predated the Aller $\phi$ d, and Cushing (1967) and Davis (1967, 1969) marshalled compelling evidence that late-glacial pollen fluctuations indicated progressive deglaciation with no major reversals in the northward movement of plant communities. This led pollen workers to invoke nonclimatic causes for the supposed major readvance to the Milwaukee-Muskegon area (surging, Wright, 1971b) and to challenge the completeness and/or the sensitivity of the pollen record (e.g., Saarnisto, 1974). Our model of deglaciation (Fig. 2) indicates progressive deglaciation (continuous warming) with only minor interruptions (Manitowoc Till, Twocreekan retreat, Two Rivers Till) during late Woodfordian through Greatlakean time and therefore appears to begin bringing the geological and palynological evidence into harmony. No surging or unrecorded cooling is required.

On a more local basis, West (1961) published two undated pollen diagrams that bear directly on the TwocreekanGreatlakean pollen problem. West's Disterhaft core was from a site on "Cary Till" outside the red drift limit. His Seidel Lake core came from a kettle developed on Two Rivers Till that overlies the Two Creeks forest bed. Both sites contained basal sediments with high values of spruce pollen. The Disterhaft site was resampled for radiocarbon material; the top of the spruce zone was dated at $11,150 \pm 160$ B.P. (WIS-441) (Bender et al., 1971, p. 479), which agrees well with other determinations of this pollen zone boundary in the region (Wright, 1971a). At the Seidel Lake site the transition from a spruce-herb to a spruce-alder-fir assemblage is now dated at $11,620 \pm 110$ (WIS-641, Bender et al., 1975 , p. 131).

A number of events must have taken place during the time between the destruction of the Two Creeks forest and the beginning of the pollen record at the Seidel site. Two Rivers ice had blocked northward drainage from Lake Michigan and drowned the Two Creeks forest by 11,850 B.P. The Two Rivers ice continued its advance to a position within the basin just south of Two Rivers, Wisconsin, depositing till over the lakesediment-covered Two Creeks horizon. The Two Rivers ice then retreated, exposing the Seidel site south of Kewaunee, Wisconsin. Presumably time was required to melt a block of Two Rivers ice to form the Seidel Lake depression by 11,620 B.P. By this reasoning, we conclude that the Two Rivers ice was present in the Two Creeks area for but a fraction of the time during this brief interval.

\section{SUMMARY}

(1) Our conclusions regarding ice-front positions during both ice advances and retreats necessitates reappraisal of the relative importance of some well-known late-glacial events and suggests a new 
pattern of deglaciation for the Lake Michigan basin. Most authors of the past 20 years have reported a rather regular retreat from the Lake Border moraines, with a minor oscillation marked by the Port Huron moraine(s) and then an extensive Twocreekan Substage deglaciation followed by a major post-Twocreekan advance (formerly Valders). We emphasize the major oscillation between the times of the Lake Border and Port Huron moraines, followed by a gradual retreat from the outer Port Huron limit (Shorewood till, Fig. 2) interrupted by a minor standstill (Inner Port Huron-Manitowoc), a retreat (Twocreekan) and readvance (Two Rivers). No Woodfordian or younger readvance was as extensive as had been the preceding one. This interpretation may explain the apparent lack of a major postTwocreekan readvance in other parts of the country and may also argue for a normal, climatically controlled deglaciation rather than surging as previously suggested. Wright's (1971) arguments for surging in the Lake Michigan basin were very logical when presented, for they were structured around the thenaccepted $320-\mathrm{km}$ post-Two Creeks ("Valders") readvance.

(2) We show that the post-Two Creeks ice advance was neither as extensive in time nor in space as was originally believed. It may never be possible by the radiocarbon technique to correlate between sites such a short interval as the Two Rivers advance (Evenson and Mickelson, 1974). Likewise, in the Lake Michigan basin it may be impossible to distinguish response of vegetation to a change in regional climate from a response caused by expanded proglacial lakes and the presence of the wasting Two Rivers ice. Indeed, if the Two Rivers Till resulted from a short-lived, very local readvance (less than $125 \mathrm{~km}$ ) occasioned by a favorable combination of climatic and/or topographic factors, then the absence of a documented response in the pollen record is easily understood, and in fact should be expected.

(3) We propose the term "Greatlakean" as a replacement for the timestratigraphic term "Valderan." Our reasons for this revision are multiple. First, our demonstration that the type-Valders Till is pre-Twocreekan (Woodfordian) invalidates the definition of the Valderan Substage as proposed by Willman and Frye (1970). Second, the continued use of Valderan for a time-stratigraphic unit that does not include the type-Valders Till both is confusing and violates the intent of the Code of Stratigraphic Nomenclature (American Commission on Stratigraphic Nomenclature, 1961; Art. $32 \mathrm{c}, \mathrm{d})$ regarding duplication of rockstratigraphic and time-stratigraphic names. We replace "Valderan" (named in 1960) rather than "Valders Till" (named in 1943) on the basis of priority as defined by the Code of Stratigraphic Nomenclature (Art. 11). Third, through repeated usage, the Valderan has come to be associated with a period of marked readvances (surging?) in the Great Lakes basins-a concept which we can now demonstrate to be unnecessary.

\section{REFERENCES}

Alden, W. C. (1918). "The Quaternary Geology of Southwestern Wisconsin." United States Geological Survey Professional Paper 106, $365 \mathrm{pp}$.

American Commission on Stratigraphic Nomenclature. (1961). Code of stratigraphic nomenclature. Bulletin American Association Petroleum Geologists 45, 645-665.

Andersen, S. T. (1954). A late-glacial pollen diagram from southern Michigan, United States of America. Danmark's Geological Undersoegelse, Series II 80, 140-155.

Bender, M. M., Bryson, R. A., and Baerreis, D. A. (1971). University of Wisconsin radiocarbon dates IX. Radiocarbon 13, 475-486.

Bender, M. M., Bryson, R. A., and Baerreis, D. A. (1975). University of Wisconsin 
radiocarbon dates XII. Radiocarbon 17, 121-134.

Black, R. F. (1966). Valders glaciation in Wisconsin and Upper Michigan: A progress report. In "Great Lakes Research Conference, 9th, Chicago, 1966, Proceedings." Ann Arbor, Univ. Michigan, Great Lakes Research Div. Pub. 15, pp. 169-175.

Black, R. F. (1970). "Glacial Geology of Two Creeks Forest Bed, Valderan Type Locality, and Northern Kettle Moraine State Forest." Wisconsin Geological and Natural History Survey Information Circular 13, $40 \mathrm{pp}$.

Bretz, J. H. (1951). The stages of Lake Chicago -Their causes and correlations. American Journal of Science 249, 401-429.

Broecker, W. S., and Farrand, W. R. (1963). Radiocarbon age of the Two Creeks forest bed, Wisconsin. Geological Society of America Bulletin 74, 795-802.

Chamberlin, T. C. (1878). On the extent and significance of the Wisconsin Kettle moraine. Wisconsin Academy of Science Transactions 4, 201-234.

Cushing, E. J. (1967). Late-Wisconsin pollen stratigraphy and the glacial sequence in Minnesota. In "Quaternary Paleoecology" (E. J. Cushing and H. E. Wright, Jr., Eds.), pp. 59-88. Yale University Press, New Haven.

Dansgaard, W., Johnsen, S. J., Clausen, H. B., and Langway, C. C., Jr. (1971). Climatic record revealed by the Camp Century ice core. In "Late Cenozoic Glacial Ages" (K. K. Turekian, Ed.), pp. 37-56, Yale University Press, New Haven.

Davis, M. B. (1967). Late-glacial climate in northern United States: A comparison of New England and the Great Lakes region. In "Quaternary Paleoecology" (E. J. Cushing and H. E. Wright, Jr., Eds.), pp. 11-43. Yale University Press, New Haven.

Davis, M. B. (1969). Climatic changes in Connecticut recorded by pollen deposition at Rogers Lake. Ecology 50, 409-422.

Dreimanis, A., and Goldthwait, R. P. (1973). Wisconsin glaciation in the Huron, Erie and Ontario lobes. In "The Wisconsinan Stage" (R. F. Black, R. P. Goldthwait, and H. B. Willman, Eds.), pp. 71-106. Geological Society of America Memoir 136.

Dreimanis, A., and Karrow, P. F. (1972). Glacial history in the Great Lakes-St. Lawrence region: The classification of the Wisconsinan stage, and its correlations. In " 24 th International Geological Congress," Rept., Sect. 12, pp. 5-15.

Eschman, D. F., and Farrand, W. R. (1970). Glacial history of the glacial grand valley. In "Guide Book for Field Trips, North-Central
Section," pp. 131-157. Geological Society of America Meeting, East Lansing Mich., Michgan Basin Geological Society.

Evenson, E. B. (1973a). Late Pleistocene shorelines and stratigraphic relations in the Lake Michigan Basin. Geological Society of America Bulletin 84, 2281-2298.

Evenson, E. B. (1973b). A reevaluation of the "Valders" limit in the Lake Michigan Basin. In "The 'Valders' Problem, Lake Michigan basin" (E. B. Evenson, D. F. Eschman, and W. R. Farrand, Eds.), pp. 1-29. Midwest Friends of the Pleistocene, 22nd Annual Field Conference Guidebook, Ann Arbor.

Evenson, E. B., Farrand, W. R., and Eschman, D. F. (1974). Late Pleistocene shorelines and stratigraphic relations in the Lake Michigan basin: Reply. Geological Society of America Bulletin 85, 661-664.

Evenson, E. B., and Mickelson, D. M. (1974). $A$ reevaluation of the lobation and red till stratigraphy and nomenclature in part of eastern Wisconsin, In "Late Quaternary Environments of Wisconsin" (J. C. Knox and D. M. Mickelson, Eds.), pp. 102-117. Wisconsin Geological and Natural History Survey, Madison.

Fairbridge, R. W. (1974). A regional lower boundary stratotype for the Holocene in Quebec. Amer. Quaternary Assoc., Abstract of the 3rd Biennial Meeting, p. 108.

Farrand, W. R. (1970). Revision of the Valders drift border of the Lake Michigan lobe. Geological Society of America, Abstracts with Programs 2, 387.

Farrand, W. R. (1976). Was there really a Valders? Michigan Academician 8, (in press). Farrand, W. R., and Eschman, D. F. (1974). Glaciation of the Southern Peninsula of Michigan: A review. Michigan Academician 7, 31-56.

Farrand, W. R., Zahner, R., and Benninghoff, W. S. (1969). "Cary-Port Huron Interstade: Evidence from a Buried Bryophyte Bed, Cheboygan County, Michigan," pp. 249-262. Geological Society of America, Special Paper 123.

Frye, J. C., and Leonard, A. B. (1965). Quaternary of the Southern Great Plains, In "The Quaternary of the United States" (H. E. Wright, Jr., and D. G. Frey, Eds.), pp. 203216, Princeton University Press, Princeton.

Frye, J. C., and Willman, H. B. (1960). "Classification of the Wisconsinan Stage in the Lake Michigan Glacial Lobe." Illinois Geological Survey Circular 285, 16 pp.

Frye, J. C., Willman, H. B., and Black, R. F. (1965). Outline of glacial geology of Illinois and Wisconsin. In "The Quaternary of the 
United States" (H. E. Wright Jr., D. G. Frey, Eds.), pp. 43-61, Princeton University Press, Princeton.

Frye, J. C., Willman, H. B., Rubin, M., and Black, R. F. (1968). "Definition of Wisconsin Stage." United States Geological Survey Bulletin 1274-E, 22 pp.

Frye, J. C., and Willman, H. B. (1973). Wisconsinan climatic history interpreted from Lake Michigan lobe deposits and soils, In "The Wisconsinan Stage" (R. F. Black, R. P. Goldthwait and H. B. Willman, Eds.), pp. 135-152. Geological Society of America Memoir 136.

Hopkins, D. M. (1975). Time-stratigraphic nomenclature for the Holocene epoch. Geology 3, 10.

Hough, J. L. (1963). The prehistoric Great Lakes of North America. American Scientist 51, 84-109.

Hughes, O. L. (1956). "Surficial Geology of Smooth Rock, Cochrane District, Ontario." Canada Geol. Survey Paper 55-41, 9 pp.

Hughes, O. L. (1965). Surficial geology of part of the Cochrane district, Ontario, Canada, In "International Studies on the Quaternary" (H. E. Wright, Jr. and D. G. Frey, Eds.), pp. 535-565. Geol. Soc. America Spec. Paper 84.

International Subcommission on Stratigraphic Classification (1970). Preliminary report on stratoty pes-Rept. No. 4. In "24th International Geological Congress, Montreal" (H. D Hedberg, Ed.), 39 pp.

Leighton, M. M. (1933). The naming of the subdivisions of the Wisconsin glacial age. Science 77, 168.

Leighton, M. M. (1957). The Cary-MankatoValders problem. Journal of Geology 65, 108-111.

Lemke, R. W., Laird, W. M., Tipton, M. J., and Lindvall, R. M. (1965). Quaternary geology of Northern Great Plains. In "The Quaternary of the United States" (H. E. Wright, Jr., and D. G. Frey, Eds.), pp. 15-27. Princeton University Press, Princeton.

Leverett, F. (1899). "The Illinois Glacial Lobe." United States Geological Survey Monograph 38, $817 \mathrm{pp}$.

Leverett, F. and Taylor, F. B. (1915). "The Pleistocene of Indiana and Michigan and the History of the Great Lakes." United States Geological Survey Monograph 53, 529 vo.

Lineback, J. A., Gross, D. L., and Meyer, R. P. (1974). "Glacial Tills Under Lake Michigan." Illinois Geological Survey Environmental Geology Note 69, $48 \mathrm{pp}$.

Martin, H. M. (1955). Map of the Surface Formations of the Southern Peninsula of
Michigan. Michigan, Dept. of Conservation, Geol. Survey Division, Publication 49.

Melhorn, W. N. (1954). Valders glaciation of the Southern Peninsula of Michigan. Ph.D. Dissertation, University of Michigan, Ann Arbor, 178 pp.

Mickelson, D. M., and Evenson, E. B. (1975). Pre-Twocreekan age of the type Valders till, Wisconsin. Geology 3, No. 10, 587-590.

Mörner, N. A. (Ed.). (1973). The PleistoceneHolocene boundary. A proposed boundarystratotype in Gothenburg, Sweden. International Quaternary Association (INQUA) symposium. The Boundaries of the Pleistocene, Stockholm, $163 \mathrm{pp}$.

Mörner, N. A. (1970). Comparison between Late-Weichselian and Late-Wisconsin ice marginal changes. Eiszeitalter $U$. Gegenwart 21, 173-176.

Prest, V. K. (1970). Quaternary geology of Canada. Ch. XII "Geology and Economic Minerals of Canada," Chap. XII, pp. 676-764. Gov. Geol. Rept. no. 1, 5 th Ed., Dept. Energy, Mines and Resources, Ottawa.

Richmond, G. M. (1965). Glaciation of the Rocky Mountains, In "The Quaternary of the United States" (H. E. Wright, Jr., and D. G. Frey, Eds.), pp. 217-230. Princeton University Press, Princeton.

Saarnisto, M. (1974). The deglaciation history of the Lake Superior region and its climatic implications. Quaternary Research 4, 316339.

Schneider, A. F., and Keller, S. J. (1970). Geologic map of the $1^{\circ} \times 2^{\circ}$ Chicago quadrangle, Indiana, Illinois, and Michigan: Bloomington, Indiana Geol. Survey, scale $1: 250,000$.

Thwaites, F. T. (1943). Pleistocene of part of northeastern Wisconsin. Geological Society of America Bulletin 54, 87-144.

Thwaites, F. T., and Bertrand, K. (1957). Pleistocene geology of the Door Peninsula, Wisconsin. Geological Society of A merica 68, 831-879.

Terasmae, J. (1972). The Pleistocene-Holocene boundary in the Canadian context. In "24th International Geological Congress, Sect. 12, Quaternary Geology, Montreal, 1972," pp. 120-125.

Willman, H. B., and Frye, J. C. (1970). "Pleistocene Stratigraphy of Illinois." Illinois Geological Survey Bulletin 94, 204 pp.

Willman, H. B., Atherton, E., Buschbach, T. C., Collinson, C., Frye, J. C., Hopkins, M. E., Lineback, J. A., and Simon, J. A. (1975). "Handbook of Illinois Stratigraphy." Illinois State Geological Survey Bulletin 95, 261.

West, R. G. (1961). Late and post-glacial 
vegetational history in Wisconsin, particularly changes associated with the Valders readvance. A merican Journal of Science 259, 766-783.

Wright, Jr., H. E. (1971a). Late Quaternary vegetational history of North America. In "Late Cenozoic Glacial Ages" (K. K. Turekian, Ed.), pp. 425-464, Yale University Press, New Haven.

Wright, Jr., H. E. (1971b). Retreat of the Laurentide Ice Sheet From 14,000 to 9,000 years ago. Quaternary Research 1, 316-330.

Wright, Jr., H. E. (1973). Tunnel valleys, glacial surges, and subglacial hydrology of the superior lobe, Minnesota. In "The Wisconsinan Stage" (R. F. Black, R. P. Goldthwait, and H. B. Willman, Eds.), pp. 251-276. Geological Society of America Memoir 136.

Wright, Jr., H. E., Winter, T. C., and Patten, H. L. (1963). Two Pollen diagrams from southeastern Minnesota: Problems in the regional Late-Glacial and Post-Glacial vegetational history. Geological Society of America Bulletin 74, 1371-1396.

Zumberge, J. H. (1960). Correlation of Wisconsin drifts in Illinois, Indiana, Michigan, and Ohio. Geological Society of America Bulletin 71, 1177-1188. 